\title{
CHARACTERISTIC FEATURES OF THE BANTU DIALECT "BAKWIRI" USED IN THE CAMEROON MOUNTAINS
}

\section{COMPARED With SOME OTHER RELated DIALECTS.}

THE following work is the outcome of a three years' investigation pursued in the Cameroons country, where during my sojourn among the tribes of the Bakwiri, Isubu, Bakundu, and Dualla I was necessarily forced to studv them and their languages.

Continual intercourse with the first named of these, the Bakwiri and Isubu tribes, gave me the opportunity of becoming well acquainted with their languages; I was not able to gain so much acquaintance with the tongues of the Bakundu and Dualla.

The best known of these in Europe is the Dualla tongue, into which A. Saker has translated the Scriptures, and of which he has also compiled a grammar and dictionary.

I know of no works whatever concerning the Isubu language, though there must be some such, seeing that missionaries have long been among them.

Mr. A. Thomson has left a short vocabulary of the principal words in the Bakwiri tongue; but it is very inadequate, and includes many words borrowed from the Isubu.

There is nothing printed, as far as I know, in the Bakundu.

The above mentioned languages constitute on the West Coast of Africa, the most outlying (northern) group of the Bantu. The succeeding group (going further along the coast to the north and west) of the Efik languages (belonging to old Calabar) is not at all related to the Cameroon dialects, and belongs to the Ibo group. So far as I can assert with certainty, the southern branch of the Rio del Rey towards the west, constitutes the boundary of these two branches of African languages. 
From the lists of words collected by Johnston on the Congo, we may infer on comparing them with those in our own group that the Bantu tongues have a great resemblance to one another; this resemblance is in fact so close between members of this same group that the languages belonging to them may often be styled simply "dialects."

This similarity strikes the traveller not only in the above four related dialects, but even between them and the idioms of the tribes of Benga (or Venga) and the Bakele; so that this group, to which belong the languages of the Cameroons, is not composed of them only, but must include the races lying to the south of them together with the Benga and Bakele, that is to say, must stretch its southern boundary to the Gaboon (near the peninsula of San Juan). The northern boundary is formed as already stated, by the Cameroon mountains, and especially by the inhabitants of its north-western portions, or the tribe of Mbomoku. If we should attempt to define its boundary towards the east, this would necessitate future explorations into the interior.

As an example of the degree of similarity subsisting between the languages of this group, the following table will suffice, exhibiting a few words in the six languages above mentioned.

\begin{tabular}{|c|c|c|c|c|c|c|}
\hline $\begin{array}{c}\text { English. } \\
\text { Man . . . } \\
\text { Woman. . . }\end{array}$ & $\begin{array}{l}\text { Bakwiri. } \\
\text { motu } \\
\text { maitu }\end{array}$ & $\begin{array}{l}\text { Isubus. } \\
\text { motu } \\
\text { maitu }\end{array}$ & $\begin{array}{l}\text { Dualla. } \\
\text { mota } \\
\text { mutu }\end{array}$ & $\begin{array}{l}\text { Bakundu. } \\
\text { mome } \\
\text { mutu } \\
\text { maitu }\end{array}$ & $\begin{array}{l}\text { Benga. } \\
\text { moto } \\
\text { maitu }\end{array}$ & $\begin{array}{l}\text { Dikele. } \\
\text { muji } \\
\text { miali }\end{array}$ \\
\hline Water . . & maliba & madiba & madiba & madiba & miba & madiba \\
\hline ire . . . & mea & ea & nea & $\mathrm{moz}$ & ea & veja \\
\hline Eye ... & diso & diso & diso & miso & dio & disu \\
\hline One ... & mo, moko & eoko & eo & moko & poko & eoto \\
\hline Town & mboa & mboka & mboa & mbuka & mboka & akodi \\
\hline Way.... & ndtia & njia & ngea & nja & njea & njeta \\
\hline Hand & tia & dika & dia & ikadu & lika & dikonji \\
\hline Tree . . . & be & belli & beli & bóleh & eli & dzeli \\
\hline
\end{tabular}

Other words, for instance, the chief adverbs denoting quantity or time, the equivalents for "much," "to-day," "to-morrow," etc., differ greatly from one another.

As for example, while in Bakwiri and Bakundu libua and 
dibua signify "much," in Dualla, this is gita. "To-day" is in Bakwiri and Isubu ja ono, in Dualla it is enge, and in Dikele bo. "To-morrow" is in Bakwiri muelle, in Isubu keke, in Dualla kieri, in Bakundu chana, in Benga vake, and in Dikele nakval ia.

We now proceed to the general system of sounds in the Bakwiri dialect, with the observation of some characteristic changes taking place in other dialects of the Cameroons.

VOWELS.

$\bar{a}$, as in "calm-" bātu (people), áfefé (great man, illustrious), äsu (ours).

$a$, as in " master-" maliba (water), kalati (paper), bati? (how nuch?).

$a$, like the English $u$ in "under," as mandene = munndeyny.

$\bar{e}$, sounds like $e i$ in "vein"; the $e$ inclining towards $i$ at the end of the sound, fenja (new, recent), (15) fenda (a man of strong will).

$e$, as in "met-" ke (but), fefe (another), meke (eggs).

$i$, as in "bit_" minda (old), biländi (brandy), ikeki (eyebrow), iluka (bottle).

$\bar{o}$, as in "bone" ; often a sound between $\bar{o}$ and $\bar{u}$, as mōtu (a man) 16, mömi (a male animal), motōba (six).

$\hat{b}$, as in "store-" móko (one), mókutu (boy), mokóko (iron staff) 0 , as in "not."

$\bar{u}$, as in "rule_" $\bar{u} b a$ (a fowl), mokiutu (boy), bübi (bad, a wicked deed).

$u$, as in "put-" kundi (rice), ndutu (blue cloth).

Diphthongs (of the vowel repeated).

aa, baali (female animal), baango (reason), baambele (sick nurse mid-wife), baaseli (clients).

oo, mookoiele (teacher).

uu, ulu (above), ueleh (a species of talisman).

Diphthongs (of different vowels).

$a i, o i, e i$, baikaise (judges), baitu (women), Bailch 1 (a peace. ful man, not a quarreller), moilédi (a persecutor), meinde (a foot).

1 The $\operatorname{sign} \beta$ is a labial between $b$ and $v$, like that in the Spanish Estevan or Esteban. 
$a u$, as maudza (palm oil) (17), mauka (prisoner), (the sounds running into each other).

The diphthong composed of a small $u$ above the following vowel indicates a very short sound running into that below it, $a, a, a, e, i$, as $m^{*} b a$ (to-morrow), bam (good), $a^{*}$ (thou), $i d i$ (inanimate), ulu (up), eleh (a kind of talisman).

\section{Palatal :-}

CONSONANTS.

$j(d \check{z})$ as in English : jetiti (darkness), njasu (scissors).

$y$ as in English: $y \delta k o$ (one), yiuba (fowl), yoßo (a kind of amulet).

$r, l$, quite as in Slavonic or European languages generally.

Both these sounds are used indifferently in the same words, and this is a sort of dialectic distinction, since the Bakwiri most generally use $l$, the Isubu more often $r$, as mukala (a white man) in Bakwiri, would be in Isubu mukära.

One of the islands in the bay of Ambas is called by the Bakwiri Mondole; many of the Isubu natives say Mondori.

$n$, as in na (I), anäne (to struggle), motüni (old men), bäna (children).

$\check{c}(c h)$ is frequent in Bakundu, as čana (chana) (to-morrow), cham or cam cham (quick), choma or com (a little), also in Bakele; but in the Bakwiri, as in other tongues, very rare, only in a few words as chom-chom, (com-com), (a brass armlet), or cha (ca), (a word to drive away dogs); it however often inclines to be $s h$.

\section{Guttural :-}

$k, k a ̈ b i$ (antelope), kalati (paper).

$g$, (hard) is very rarely used in Bakwiri, but frequently in Dualla.

gina (strength), ganda (nail).

$A$, ( $\pi g^{\prime}$, with the $u v u l a$ ), a very frequent sound, as froa (a pig), itäna (foot), igïndja (a kind of mat), angile (a waggon), alingaini (I love), nonde (the moon), fiamba (fetish), ngombe (iguana).

$h,(\mathrm{smaI})$ is used for an aspirate after a vowel, as Mondole lobah (the sun), after the vowel $i$ no aspirate is heard. 
Dental :-

t, tàta (father), dibātu (cloth), etūlo (rat), tīa (to beat). $d$, dibätu (cloth), di (we), diendi (knife), dina (name).

nd, Mondoleh, kundi (rice), ndö (pepper, ndène (great), ndäbo (house).

s, sūe (fish), sätz (little), Bangisē (to frighten away, safigo) (lord), sa-ngómo (native dance).

\section{Labial :-}

$P$, is rare in Bakwiri ; it occurs in some names of towns, as Sopo, Mapanja, and in the word poso (a present), but in this the sound is nearly $p f$. On the contrary the Dualla and Bakundu abound in $p$. Nearly everywhere where the Bakundy put $f$ these dialects use $p$. The Isubu uses both $p$ and $f$, but inclines to the Bakwiri habit of using $f$ more than $p$.

$b$, in bätu (people), bakütu (boys), bue (tree), baba (two).

$m b, m b \bar{u} k \dot{e}$ (dumb), mbaa (dog), mboā (town). In the word inambala or mambara (a cat), the $m$ belongs to the first syllable (mam-bara).

$\beta$, as in the Spanish, or modern Greek. Bolo (cause), joßo (talisman), motu-Bokiuba (a smith), Bäkise (to be convinced), $\beta a \beta i s e$ (to dry, or smoke meat or fish).

m, mötu (a man), kem (no), am (my), molanga (a lie), mwali (a female animal).

$f$, often labial almost like $f w$, as afêfe (a dignitary), fo (far off), fako (mountain), fêfe (other).

$v$, exists, but is rare in Bakwiri, as mäve (breast).

\section{SINGULAR AND PLURAL PREFIXES.'}

The plural is formed by a prefix, which sometimes, through degradation of form, is not always recognisable. A few words however remain quite unchanged.

The general rules, by which the words expressing the plural

1 The editor has somewhat changed the tenour of this paragraph. M. Rogozinski, when be wrote these notes, was not fully aware that he was describing a regular system of prefixes. Mó- or $M I u$-is the first ; $B a-$ is the second; $M 0_{0-0}$ or $M u$-is the third; $M i$-the fourth; $D i$-is the fifth ; $M F a-$ the sixth ; $I-$ or $E$-the seventh ; $B e$ - the eighth; Bo-the fourteentb of the regular Bantu prefixes; see Bleek's Comparative Gramniar. 
are formed, so far as I could construct them from the comparison of numerous examples, are pretty much as follows :-

$B \bar{a}$ is the plural prefix of all those words which in the singular begin with mo, many of which have to do with the human beings. These words have generally a long $m \bar{o}$ as singular prefix, as mōtu (man), plural bātu, mōkūtu (boy), bākütu (boys), möembedi (singer), bāembedi (singers), möantbedi (a hunter), plural baanbedi; mōambele (a person taking care of another), pl. bāambeli, moläna (wife), pl. balana; maitu (woman), also makes baitu; but also muaitu, because the word was originally moaitu, which is still used in the Isubu language and in some parts of Bokwiri (as the Bakwiri country is called).

$M i$ is the usual plural prefix of such words as have mo, $m u$, $b o, b u$, in the singular. As: molenge (sheep), pl. milenge; mokāmi (thought), pl. mikämi; mokbko (an iron staff), pl. mikbko; muèma (heart), pl. miema; muemba (companion), pl. miemba; muange (a line), mienge; boso (a face), pl. miòso; bôlo (a boat), pl. miôlo; bué or buéli (a tree), pl. mieli; buänga (nut of the oil palm), pl. miañga. The following singular and plural prefixes are as yet unclassified: lĩa (a palm), pl. dĩa; lifefia (novelty), pl. difefia.

$M a$, or by contraction before $i, m^{\prime}$, is the plural prefix of many words beginning with the long $d \bar{i}$, as dia (hand), pl. mãa; diāi (stone), pl. māiai; diāiàbi (a spider), pl. mãaūbi; dīkàta (shoulder), pl. mäkāta; disiza (a species of grain), pl. mäsīa. Also: diso (eye), pl. miso; diofi (a river), pl. miofi.

$B e$ is the plural prefix of a great number of words ending in $i$ and $e$, as itulibi (amount of money), pl. betulibi. Itungi (a pledge), betuffgi pl. ; ekütu (cap), pl. bekütu ; eèmbi (a tame animal), beèmbi (a flock); efëha (noveltv). pl. befena; ibambu (plank), bebambu (planks).

The prefix $m a$ is used to signify the plural number for words beginning with $n d, m b, n g$; as ndäbo (house), pl. mandäbo; mbōa (town), pl. mambōa.

Some nouns do not change at all : as siue, (rarely sizi) (teeth), kalati (paper, or book), uea, (fire), kunga (boat).

Besides these we meet some irregular forms of the plural; as for example ndoko (pepper), in the pl. yundoko; uba, (fowl), pl. yuba. 


\section{ALLITERATION.}

The Bakwiri dialect, like other related idioms, is distinguished by so-called alliteration. This arises from the fact that the initial syllable of a word assimilates, or accommodates itself to the initial sound of the word preceding it.

Such words are especially, possessive words, prepositions as well as numerals from $\mathrm{I}$ to 5 .

Thus in their original form these possessive words are: am (my), ongo (thy), acu (his), asu (our), anyo (your), abu (their).

But if conjoined with nouns they must undergo a sort of alliteration :-

motu mam (my man), not motu am.

bätu bam (my men).

Bolo bam (my boat), miôlo mam (my boats).

diso dam (my eye).

yongo yam (my pot).

Before ndābo, mbōa, kunga (boat), fäi (an oar), sango (lord) the possessive word remains unchanged, thus: sango am, ndabo am, kunga am, fäi am.

If the first word begins with $n$, then the possessive takes $y$ at the beginning thus : nama-becomes nama yam; ngundia-yam, ngoa yam, naka yam.

The same thing takes place with the words offgo, $a u$, asu, anyo, abu ; as mōtu mongo, mōtu mau, mätu mäsu, etc., diso, dongo, diso dāu, diso dasu, etc., sāngo ongo, ndabo äu, mboā asu, ngōa anjo, kunga abu.

The possessive particle $a$ changes on a similar plan, as : $y a$, ma, la (,) ba.

We cannot say muema a motu (the heart of the man), but muema ma mötu; not Bolo a motu, but Bolo ba motu (the canoe of the man), not diso a mukara, but diso da mukara (the eye of the white man) and dina da ekiimi, (the name of the country), diendi da nyango (the knife of the mother). However they say: sango a Mondoleh (the chief of Mondoleh), sui a $F_{0}$ (fish from Victoria), i.e. the settlement of Victoria on the coast; kunga a Likabo (a boat of Fernando-Po); pāi a sango (the chief's oar), yongo ya maitu, (the pot of the woman); yuba ya nyango (the mother's fowls), lia la fako (mountain palm); tata la mokutu (the 
father of the boy); tulungi la mukara (the coffer of the white man).

NUMERALS ARE SIMILARLY CHANGED.

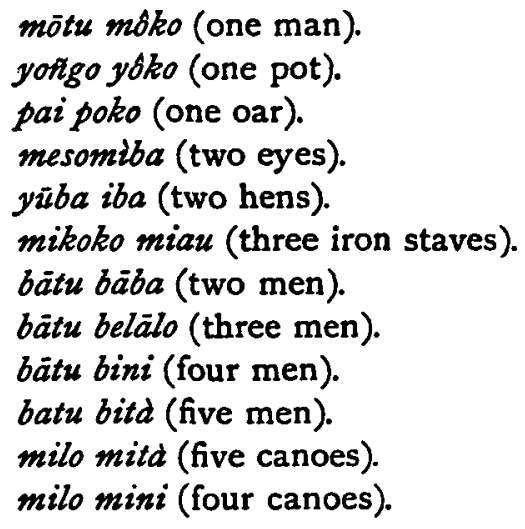

\section{CONTRACTION.}

Whole syllables disappear, and vowels coming together undergo contraction.

$b \bar{a} l \hat{b}$ (good men), instead of $b a \bar{t} u$ aloli.

Bämué (honest men), instead of batu ba muema.

yāru (come here), instead of ya änu.

$b u \hbar a b b$ (one day) instead of $b u \pi a b b k o$.

bue (tree), instead of bueli (compare the Isubu bueli).

nasemedi (I won't), for na asi emedi.

$b a b \delta b i$, sometimes $b a b \delta b e$ (wicked people), instead of $b \bar{a} t u-b a-$ $b \bar{u} b i$ (people of evil, people of violence). This latter name has become stereotyped, to signify the Germans, after their expeditions up the Cameroon river and in the mountains, in 1881 and 1885 .

ndzunu ? (who's there?) instead of ndsu äru ?

COMPARISON.

A very favourite form of the comparative in these dialects is by intensifying the sense of an expression (of adjectives, adverbs, and even of nouns in the plural).

In the Bakwiri dialect the word $\bar{a} k \dot{a}$ (much, very) elsewhere te is seldom used for comparison; it generally serves for the creation 
of compound phrases, as : àkämuèma (a brave man)-literally "much heart."

$\bar{a} \bar{k} \bar{f} f e n d a$ (courageous) literally "very much not frightened." $\bar{a} k \bar{a} f e f e$ (the first chief) litera!ly "very illustrious."

But the usual form of comparison is by repeating a word, as : mondène / ndène (great, Great).

ten ! ten / (little, little)-almost nothing.

$b \hat{u} b i$ । bùbil bübi! (bad, bad) not unfrequently in order to give emphasis to the repetition, the last syllable is strongly accented.

aloli! aldli! (pretty! very pretty!).

änu änu! (here, all here!).

bàtu $b_{\bar{a}} t u-b a \bar{t} u$ (many men),

bāna! bãna! (a whole lot of children).

fo-fofo (far, far off!).

tumbi-tumbidī (far, very far!).

In many words there will be two different syllables for the same thing, but in particular, to the first syllable of a word beginning with a vowel the letters $l, n, w, p$ will be attached in the second repetition.

änga-länga (to read, to preserve).

$\bar{a} \overline{\bar{a}}$-Lāna (to tear).

aya-laya (to forbid).

itôngi-litôngi (to surround).

ini-lini (to weary).

if üle-lifüle (to correct).

enja Lenja (to deceive).

eni-leni (to look).

THE PAST TENSE.

The past tense is usually made by the change of the final vowel $a$ or $e$ into $i$ or if that vowel is itself $i$, an additional stress is laid upon the final $i$ for the past tense. Besides this however there are many irregular forms of the past. Examples :-

battä (to add), -batti (I did add).

bāndd (to forget), -bāndi (I forgot).

bandā (to hide), bandi (I hid).

bänga (to refuse), bangi (I refused). 
angbd (to shoot), angbi (I shot).

agbud (to go up), agbi (I went up).

$a b \bar{a}$ (to sell, to divide), $a b i$ (I sold).

anāna (to fight), anāni (I fought).

asā (to desire, to seek), asi (I desired).

àyā laya (to forbid), āyi (I forbade).

äflga lāñga (to count, to reckon), ãngi.

$\bar{a} \mathfrak{i} \bar{a}$, laña (to scrub, to rub), āfí (past tense).

tuta (to chase, to pursue), tutī (past tense).

tia (to beat), $t i$ (past tense).

tangd (to pay), tang $\overline{~(p a s t ~ t e n s e) . ~}$

$o k \bar{a}$ (to be), oki (past tense).

owd (to kill), owwi (past tense).

$k e n d \bar{\varepsilon}$ (to go, to walk), kendi (I went).

küle (to end), kuli (also kulele).

babise (to smoke over a fire), babisi.

bakisē (to convince oneself), bakisi.

teme (to maintain oneself? to stand), temi

diende (to whittle), diendi.

timbe (to return), timbi.

$\partial f$ (to have), ofi.

Also:-

andd (to buy), past tense maandd.

alingani (to love), remains alingani in the past.

takia (to be in need), tikéli.

bate (to shake hands), bate.

àtoe (to warm oneself), ätoe.

$b i a$ or $b \bar{e} \bar{a}$ (to hear), is $b i \bar{e}$ and $b e$ in the past tense.

The numerals in Bakwiri are as follows :-

1. $m \hat{b} k o(y b k o, p \delta k o, m b, b \delta)$.

2. beba, miba, iba.

3. biyau, belälo.

4 bini, mini.

5. bità, mitd.

6. motaba.

7. samba, isamba.

1 This is a relic of the regular and archaic Bantn preterite inflection.-ED. 

8. uambi.
9. Libua, dibua.
10. djum.
II. djum na joko.
12. djum na beba, etc.
20. mbangi.
21. mbangi, na mo, etc.
30. mualalo.
40. mini, mini.
50. minimitd.
60. minimotōba.
70. minisamba.
80. miniuambi.
90. minilibua.
9r. minilibua na mo, etc.
100. ebuè.

In the Isubu dialect the numerals are almost the same; there is however a different word for 20 , which is $d u$. Five is - tano (metano, sitano) 10 in the island of Mondoleh and in Bota is called djum, but in Bimbi isdka. Multiples of 1o are derived in Isubu from the name for 30 (sakilalo), so that 40 is sakilalo na djum (thirty and ten) (or na isaka; 50, sakilalo na du; 60 iba sakilalo; 70, iba sakilalo na djum (or na isaka), etc. In the Bakundu the quinary system prevails. The numerals in this are:-1, moko; 2, beba; 3, ilaro; 4, bini or mäne; 5, betd; 6, betdnedko; 7, betdnabeba; 8, betano ilaro; 9, betd na bini; 10, londera; 20, do; 100, muna betd.

\section{A FEW GENERALLY DESCRIPTIVE ELEMENTS.}

Certain elements serve to form a number of words with a general meaning :-

$M \bar{o}$ (in the plural $b a$ ) conveys a general notion of a human being, simply and in all relations as: mōtu (a man) mōkitu (a boy), mōāitu (a woman), mōembeddi (a singer), mōangbèdi (a hunter), mōambile (one taking care of another), mölana (a woman), etc.

$\hat{N}_{g}, n j, n$ usually begin the names of all the larger wild beasts; as: ndzo (a leopard), ndizu (an elephant), ndzika (a 
FEATURES OF THE BANTU DIALECT "BAKWIRI" 4II

buffalo), flaka (a cow), figōa (a sow, or wild boar); sa-asä (to seek) is the root of the words móaseli baiaseli (a seeker, seekers), - asase (to beg).

Closely allied to these are some compound expressions.

\section{COMPOUND WORDS.}

möokuēli (a scholar), from mötu (a man), and okud (to learn). asaoli (rudely, not nicely), from asi-aloli.

mojibedi (a thief), from mōtu and jiba (to steal).

moitidi (a partisan, adherent), from mōtu and ite (to follow one

to go behind him).

sangome (a dance to the accompaniment of the drum), from sa (a dance), and figomó (drum).

saftgombōa (a chief), from sango (a lord), and mbōa (a town).

WORDS IMITATING NATURAL SOUNDS.

chom-chom, brazen armlets, worn in the greatest profusion on the arms.

Agingi (a bell).

jetiti (dark). It is necessary to explain that when it is only just beginning to get dark in these regions, the chirping begins of countless cicadas and crickets, so that a native on hearing this continued $j i$-ti-ti-ti-ti, calls the darkness itself $i t i t i$.

cha-cha (go away!) a call to a dog.

$k \hat{b} b a-k b \hat{b} a$ (a turkey).

putu-putu (the noise of the sea waves).

njasu-njasu (scissors).

chaki-chaki (hiccup).

\section{BORROWED WORDS.}

The Bakwiri and Bakundi have fewest of these, the Isubu and Dualla most; for this simple reason that the two latter dialects being used by the natives of the coast, are naturally the most influenced by intercourse with Europeans.

Bilandi is the English "brandy."

$T i$ (in Isubu and the southern Bakwiri is simply tea).

Inki in the same is for ink. 
Na savi (Isubu), for "I don't know ;" the universal Portuguese. "Nað save."

$M a n u \bar{a}$ (man of war).

Queeni, for the Queen (Victoria).

Tümbulo, for tumbler.

Tulangi, a corruption of "trunk."

\section{PROPER NAMES.}

The Bakwiri have no distinction equivalent to Christian names and surnames. Parents give their children a name from among those in general use, sometimes two; or if the name is a common one, they add that of the father for the sake of distinction; but only in the case of adults.

Their names are derived from animals or other objects as :-

Molenge (a sbeep).

Mbüa (rain).

Monika (a penknife).

$\hat{N}$ gendo (a great lizard).

Njungo (handsome).

Ekua (the cover of a gun).

or elșe names without any meaning, as Keka, Ndibe, Ekba, Diko, Njonje.

There are usually the same names used for women as for men. Still there are a few special names for women, as Mondżua, Aune, Titi.

The natives have also invented some geographical expressions.

Thus, the island of Fernando Po, with which they have no intercourse at all, but which they can see on the horizon when the atmosphere is clear, is called by them Likäbo. The English settlement of Victoria, founded on the bay of Ambas, they call Fo. The far off country of the whites they call Mbenge.

The English are Inglisi. The Germans bätu-ba-bubi (bad men, harsh men).

\section{COLOURS.}

The Bakwiri have not a distinctive word for all colours. White as a colour is tana. Bright yellow is also called tana. Yet a white man, or European, is not called mōtu tana, but has a separate name to himself, mukara or mukati. 
Red and yellow have one equivalent: tēa.

Black is jinda, but the same word is used for dark blue and dark brown, as well as for dark green.

Green is eüla-fina (literally meaning "fresh grass").

It would appear that the Bakwiri have no separate word for blue, but I have usually heard them when they were shown green, and wanted blue, say : eüla-féria-féfe, or " another green."

Blue cloth however they style by a particular name : ndütu.

\section{RECKONING OF TIME.}

The ideas of "to-morrow" and "yesterday" are expressed by no distincr words, both alike are called muele. The precise meaning must be inferred from the circumstances, but if a more particular description is needed, the native who expressly means "yesterday" will add mbusa, Mbusa mbusa (i.e. to-morrow backwards).

"The day after to-morrow" is expressed by two days, ibinga iba. "Every day" is bünya-na-bunya, i.e. "day and day." They are fond of expressing "always" by repeating the syllable $t e$, as te, te, te.

The counting of time is by months and days; the first are naturally reckoned by the state of the moon. If they wish to denote a longer space of time and their memory serves themwhich it very seldom does-they say a thing occurred so many rainy seasons ago.

As regards the hours of the day they have a word for noonday only, muese. The rising and setting of the sun are more or less fixed points for the Bakwiri, considering that the Cameroon Mountains are only four degrees from the equator, so that setting and rising must occur all the year round at practically the same hour.

\section{REMARKS ON CONTRACTIONS.}

The syntax of these dialects is extremely simple, the native expresses himself in short sentences, also he usually omits words connecting some parts of the sentence, as for example oka (is) or the particle $a(n a, l a, j a)$, equivalent to "of." For instance : ndzu nu? (who is there?), which should be ndzuoka anu? or a ndzi (he is high souled), instead of $a$ okä $n d z i$, or sängomböa na 
$n d a b a$, instead of Sango a mbōa oka na ndabo (the lord of the town is at home), mōtu Lobba (man of God), nama Agōa (boar meat), nama haka (cow meat), and so on.

The future tense is expressed by the help of the word alingdni (I will, I desire), as alifigani tangd (I will pay), alingani of (I will have). Relations between objects are expressed by the particle $a$ (na, la, ya), (of), te nate (to) eti, a mōtu (of the man), a tata (of the father), a nango (of the mother), te tata, etc.

The personal pronoun is often omitted before the verb; for example: "I have no meat, but to-morrow I will have some," is expressed thus: (Na) Asi ofi nama yauono, nde (na) alingani of muele fungi (I forgot), instead of nafungi, abi (I sold), instead of $n a a b i$.

As to the order of words we must observe that the object must always follow the verb, the assertion after the subject, to which it belongs; as: sango tia mokutu (the lord beats the boy), motu buan aliffgani balana libua (the rich man likes many wives) mukara ônu abi ndàbo mondène na kunga moko (that white man sold a great house and one boat), motu lobo moeni ia siue fenja (the stranger fisherman brings fresh fish), nasi bandi ekumi aloli anyo / (I shall never forget your beautiful country).

To conclude, the native method of expression is short, pithy and broken. As an example I will quote the native chief Nanga Sihi's account of one of our own journeys.

Mukara agbrwi na fako, anu batu-ba Mokōnya abisē uēse uēse ! Mukara ofi muhumba-na-mbenge libua! na aftgbi! aangbii! nde Sango Mokonya ua batu na mbōa aaftgbii mayāi, na yóli na fäu na moōnye! uamise! Mukara timbembusa!

(The white man went by the mountain-here the people of Mokonya overturned all, all! The white man had guns from far away-many-and he shot, he shot; but the chief of Mokonya and the people of the town threw stones, wood, knives, earth! quickly! quickly! the white man returned!)

\section{INTERJECTIONS.}

The native exclamations are characteristic. They are usually short vowels, often repeated, partly of one syllable, sometimes of two, occasionally more. 
$\bar{a} i \hat{b}$ ! exclamation of astonishment.

$e^{h} \dot{e} /$ meaning "I understand."

i! (yes).

kem! (no!) often repeated twice.

cha / cha / "go away !" principally used to drive off dogs.

na $u i$ ! (I understand).

$e ?$ ! to express incredulity.

In uttering these exclamations an important quantity is the peculiar intonation, which it is impossible to give in writing.

We can however give some explanations in writing, at the same time answering some of those questions, which Darwin has recommended to travellers, inviting their observations among native races in these particulars.

(1) The Bakwiri native, when surprised and exclaiming ayf, opens his mouth, throwing his head backwards, raises his eyebrows, and gazes at the object or the person, which has astonished him.

(2) If on speaking to him the matter appeals to his conviction after listening attentively, he bends forward his head suddenly, throws his lower jaw forward, and calls out, making a motion with his hand, as if bowing: ehe!

(3) In making a simple affirmation he throws his head backwards, exclaiming $I$ !

(4) In ordinary quiet contradiction, he shakes his head (often turning it to one side only), calling out kem !

If, however, he becomes irritated in the argument, he adds a violent shaking of the arms.

(5) When crying cha! cha / chal the native claps his hands, and shakes his head at each repetition of cha!

(6) Na uil means "I understand," but is spoken with a cunning expression of the face. The native shakes his head, slightly raised, and lifts his eyebrows slightly.

(7) To express incredulity the native half opens his mouth, lifts one eyebrow, bends his head forward, and, looking aside, exclaims with a high-pitched intonation, e !

STEPHEN ROGOZinSKi.

(Translated by MAUde A. Biggs.) 